\title{
Transfusion pattern of blood products in a blood bank at a tertiary care hospital
}

\author{
Giridharan J. ${ }^{1 *}$, Sarada V. ${ }^{2}$ \\ DOI: https://doi.org/10.17511/jopm.2020.i06.06 \\ 1* Jeevaraj Giridharan, Assistant Professor, Trichy SRM Medical College Hospital and Research Centre, Trichy, Tamil Nadu, India. \\ 2 Sarada V., Professor, Trichy SRM Medical College Hospital and Research Centre, Trichy, Tamil Nadu, India.
}

Objectives: Blood products in modern-day transfusion practice include, Packed Red Blood Cells, Platelets, Leucocytes, Plasma, Cryoprecipitate, and individual plasma factors. The objective was to study the pattern of usage of various blood products for the commonest clinical indications and to have an overview of the production of blood components. Materials and Methods: In this study, usage of various blood products like Packed Red Blood Cells, Platelet concentrates, Fresh Frozen Plasma, and Cryoprecipitate were studied in the blood bank of Trichy SRM medical college hospital and research center, using blood bank records and correlating with clinical data during the period of June 2015 - June 2020. Observation and result: The pattern of usage among 14,511 units of blood components from June 2015 - June 2020 showed the frequency of usage of Packed Red Blood Cells was more than Fresh Frozen Plasma and whole blood. The usage of whole blood was more than Platelet concentrates and Cryoprecipitate. The most frequently used component was Packed Red blood cells - 7841 units (54\%). The second most frequently used component was fresh frozen plasma - 3889 units $(26.8 \%)$. In the next frequency whole blood- 1955 units $(13.5 \%)$, platelet concentrates - 797 units $(5.5 \%)$ and cryoprecipitate - 29 units $(0.2 \%)$ were used. Conclusion: There has been an appropriate increase in the usage of blood products to meet the clinical demand in treating the patients with an increase in pathological conditions. Specific blood component transfusion should be encouraged for specific indications to reduce non-essential overload to the patients.

Keywords: Blood components, Cryoprecipitate, Fresh Frozen Plasma, Packed Red Blood Cells, Platelets, Usage, Whole blood

\section{Corresponding Author}

Jeevaraj Giridharan, Assistant Professor, Trichy SRM Medical College Hospital and Research Centre, Trichy, Tamil Nadu, India.

Email: dr.jeeva30@gmail.com
How to Cite this Article

Giridharan J, Sarada V. Transfusion pattern of blood products in a blood bank at a tertiary care hospital. Trop J Pathol Microbiol. 2020;6(6):401-409. Available From https://pathology.medresearch.in/index.php/jopm/ar ticle/view/471
To Browse

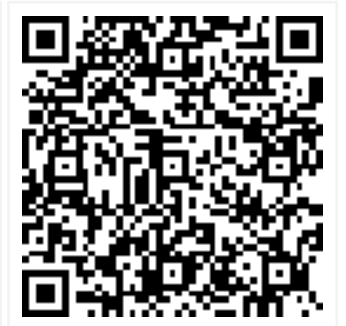

Manuscript Received 2020-07-10

Conflict of Interest No

(C) 2020 by Jeevaraj Giridharan, Sarada V. and Published by Siddharth Health Research and Social Welfare Society. This is an Open Access article licensed under a Creative Commons Attribution 4.0 International License

Review Round 1 2020-07-30 https://creativecommons.org/licenses/by/4.0/ unported [CC BY 4.0].
Review Round 2 2020-08-15

(1) Approval 2020-07-30

unding

\section{Review Round 3 \\ Plagiarism X-checker $8 \%$}

Accepted 2020-08-26

Note 


\section{Introduction}

Blood transfusion and blood conservation are complementary activities that constitute the clinical arena of transfusion medicine. Blood components can be prepared in a licensed blood bank that has the required space, specialized equipment, storage facilities, and trained personnel. The advent of blood component therapy was by use of factor VIII for hemophiliacs which commenced in the U.K in 1980, prepared by fractionation of human plasma. This is not just for checking infections, but also to minimize the other side effects of blood transfusion [1]. Transfusion of whole blood creates hazards to the patients which were noted in the past few decades. So transfusion of blood components has been considered, to be a low risk and safe procedure [2]. In the United Kingdom and other western countries, whole blood is not used for transfusion for the patients routinely $[3,4]$. With the development of PVC bags with integral tubing, separation of components can be done safely without risk of infections.
It is processed into various components and only those specifically needed by the patient are issued $[4,5,6]$.

Use of Blood Components ensures added advantages:

01. Maximized use of one unit of blood for a number of patients with the same unit.

02. Shelf life of each component is longer than in whole blood.

03. Better patient care with specific components without danger of overloading/ side effects of other unwarranted components.

04. Cost-effective blood bank system wherein cost and processing a unit of blood is shared by a number of patients compared to giving whole blood to only one patient/recipient [7-10].

Blood components used in modern-day practice include, apart from whole blood, a variety of other products, like Red Blood Cell products, Leukocyte products, Platelet Concentrates and Plasma as shown in Table-1 [11].

Table-1: Various Blood products.

\begin{tabular}{|l|l|l|l|l|}
\hline \multicolumn{1}{|c|}{ Red blood cell products } & \multicolumn{1}{c|}{ Platelet products } & \multicolumn{1}{c|}{ Leukocyte products } & \multicolumn{1}{c|}{ Plasma } & \multicolumn{1}{c|}{ Plasma derivatives } \\
\hline Packed red cells & Platelet-rich plasma & Granulocyte rich plasma & Fresh frozen plasma & Factor VIII Concentrate \\
\hline WBC poor red cells & Platelet concentrate & Lymphocyte rich plasma & Frozen plasma & Factor IX Concentrate \\
\hline WBC depleted red cells & Frozen platelets & & Cryoprecipitate & AT-III Concentrate \\
\hline Washed red cells & & & Cryo removed plasma & Factor XIII Concentrate \\
\hline Frozen deglycerolized red cells & & & & Albumin \\
\hline & & & & IV Immunoglobulin \\
\hline & & & & Rh Immunoglobulin \\
\hline
\end{tabular}

Whole Blood: According to the ASA guidelines for whole blood transfusion, acute loss of blood if more than $30 \%$ and the patient is at the risk of hemorrhagic shock, the transfusion of whole blood is the component of choice to restore blood volume and oxygen-carrying capacity[12,13,14,15]. Transfusion of whole blood has also been used for anemia in patients. But in modern-day practices replacement of whole blood by individual components plays a vital role to prevent overload to the patients [Table-1].

Packed Red Blood Cells: The guidelines for Packed Red blood cells categorized by ASA depends on the bone marrow production of red blood cells and the destruction of red blood cells. In decreased bone marrow production conditions like Leukemia and Aplastic anemia are included. In decreased red
Cell survival conditions like Hemolytic anemia and Thalassemia are included. Packed Red Blood Cells used in bleeding patients are indicated in surgical bleeding and traumatic bleeding $[16,17,18]$. In anticipated surgical blood loss $>1000 \mathrm{ml}$ or if the patient needs urgent surgery and has hemoglobin < $10 \mathrm{~g} / \mathrm{dl}$, transfusion is indicated. If there is an acute loss of blood with a reduction of $30-40 \%$ of blood volume, transfusion of RBCs along with crystalloids is indicated. Whole blood or packed red blood cells along with crystalloids are indicated for transfusion if there is acute blood loss $>40 \%$ of blood volume $[19,20]$.

Other indications for packed red blood cells include, anemia associated with incipient/established cardiac failure or if hemoglobin value $<6 \mathrm{~g} / \mathrm{dl}$, patients approaching delivery with hemoglobin value $<7$ 
$\mathrm{G} / \mathrm{dl}$, hereditary hemolytic anemias, and betathalassemia major.

Platelet Concentrates: The ASA guidelines categorize the indications of platelet transfusion according to the platelet count. Platelet counts less than $5000 / \mu l$ due to any comorbid conditions, there is an essential need of an immediate transfusion. If the platelet count range between $5000-10000 / \mu l$ and associated increased risk of bleeding due to hematological malignancies, sepsis, bone marrow aplasia, or a transplant, platelet transfusion indicated. Transfusion of platelet concentrates is needed if the platelet count is between the range of $10000-20000 / \mu \mathrm{l}$ and if bleeding present at mucus membranes, surgical incision, venipuncture site, or presence of scattered petechiae or ecchymosis $[22,23]$. Other indications include chemotherapy patients with platelet count $<20,000 / \mu \mathrm{l}$, patients having disseminated intravascular coagulation, and massive transfusion.

Fresh Frozen Plasma (FFP): It is separated from whole blood and is frozen within 6-8 hours of collection. FFP contains plasma proteins and all coagulation factors, including the labile factors $\mathrm{V}$ and VIII if stored at $-30^{\circ} \mathrm{C}$ or below $[24,25]$. The indications for FFP includes actively bleeding patients, multiple coagulation factor deficiencies as in liver diseases, disseminated intravascular coagulation, coagulopathy in massive transfusion, thrombotic thrombocytopenic purpura (TTP), familial factor $v$ deficiency, deficiency of factors II, VII, IX, X (vitamin $K$ deficiency) $[26,27]$, antithrombin III deficiency and congenital / acquired coagulation factors deficiency.

Cryoprecipitate is precipitated by specific plasma proteins derived from the fresh frozen plasma. The indications for cryoprecipitate for the conditions include hemophilia A, von-Willebrand disease, congenital or acquired fibrinogen deficiency, acquired factor viii deficiency as in disseminated intravascular coagulation or massive transfusion, and factor xiii deficiency [28-31].

\section{Materials and Methods}

Setting: Department of Pathology and transfusion medicine, Trichy SRM Medical College Hospital and Research Centre, Trichy.

Duration: June 2015 to June 2020

Type of study: Retrospective study
Sampling Size calculation: Based on previous studies and statistical formula, the sample size was determined with an alpha error of 0.05 and a power of 0.95

\section{Sample size: 14,511}

Inclusion criteria: All the blood products utilized at Trichy SRM Medical college hospital during the time of the study period were included in the study.

Exclusion criteria: Blood products that have been discarded and not utilized for transfusion, the data of blood product utilization for which the indications could not be traced.

Data collection procedure: Blood component data were collected retrospectively. Details were recorded, analyzed, and compared with the clinical data to find out the necessary indications for which the components were used.

Data analysis: Categorical variables were expressed in percentages, pie charts, and bar diagrams. The student T-test was applied for calculating statistical significance when data followed nominal distribution. Mann Whitney test applied when data followed non-nominal distribution. Nominal categorical data between the group were compared using the Chi-square test or fisher's exact test as appropriate. $\mathrm{P}<0.05$ was taken to indicate a statistically significant difference.

Ethical permission: Obtained

\section{Result}

Blood Bank of Trichy SRM Medical College Hospital and research center is licensed for the whole blood transfusion by the Department of Drug Controller, India since 2008.

Since then Whole blood transfusion has been in routine practice. Blood Component separation and transfusion has commenced since 2014 when the upgradation on the infrastructure and duly licensed by the Drug Controller of India under the relevant act was done.

The Blood Components that were prepared include Packed Red Blood Cells, Random Donor Platelet Concentrate, Fresh Frozen Plasma, and Cryoprecipitate. The main objective of the present study was to find out the pattern of usage of blood products since 2015 when the license for blood product preparation for specific indications in clinical therapy was done. 
Table-2: Usage of blood products observed during the study period.

\begin{tabular}{|c|c|c|c|c|c|c|}
\hline $\begin{array}{l}\text { Period of Usage } \\
\text { (June) }\end{array}$ & $\begin{array}{l}\text { Packed Red Blood Cells } \\
\text { (PRBC) (Units) }\end{array}$ & $\begin{array}{l}\text { Platelet Concentrates } \\
\text { (Units) }\end{array}$ & $\begin{array}{c}\text { Fresh Frozen Plasma } \\
\text { (Units) }\end{array}$ & $\begin{array}{l}\text { Cryoprecipitate } \\
\text { (Units) }\end{array}$ & $\begin{array}{l}\text { Whole blood } \\
\text { (Units) }\end{array}$ & $\begin{array}{l}\text { Total } \\
\text { (Units) }\end{array}$ \\
\hline $2015-2016$ & 457 & 70 & 194 & Nil & 1278 & $\begin{array}{l}1999 \\
(13.8 \%)\end{array}$ \\
\hline $2016-2017$ & 1067 & 108 & 222 & 2 & 644 & $2043(14 \%)$ \\
\hline $2017-2018$ & 1903 & 145 & 867 & 5 & 15 & $\begin{array}{l}2935 \\
(20.2 \%)\end{array}$ \\
\hline $2018-2019$ & 2172 & 221 & 1112 & 7 & 11 & $\begin{array}{l}3523 \\
(24.2 \%)\end{array}$ \\
\hline $2019-2020$ & 2242 & 253 & 1494 & 15 & 7 & $\begin{array}{l}4011 \\
(27.8 \%)\end{array}$ \\
\hline Total (Units) & 7841 (54\%) & $797(5.5 \%)$ & $3889(26.8 \%)$ & $29(0.2 \%)$ & $1955(13.5 \%)$ & $\begin{array}{l}14511 \\
(100 \%)\end{array}$ \\
\hline
\end{tabular}

*One Unit $=350 \mathrm{ml}$ of whole blood/ $250 \mathrm{ml}$ of packed red blood cells/ $220 \mathrm{ml}$ of fresh frozen plasma/ $50 \mathrm{ml}$ of platelet concentrate/ $15 \mathrm{ml}$ of cryoprecipitate.

The total units prepared and utilized for transfusion at Trichy SRM Medical College Hospital from June 2015 to June 2020 was 14,511 units [Table-2].

Among the total units Packed Red blood cells comprises 7841 units $(54 \%)$, platelet concentratesutilized for transfusion were 797 units $(5.5 \%)$, total Fresh frozen plasma units utilized were found to be 3889 units $(26.8 \%)$, Cryoprecipitate utilized for transfusion were found to be 29 units $(0.2 \%), 1955$ units $(13.5 \%)$ of Whole blood have been utilized as well [Table-2].

One unit of Whole blood is about $350 \mathrm{ml}$ and Packed Red Blood cells comprise $250 \mathrm{ml}$. One unit of platelet concentrates comprises $50 \mathrm{ml}$. A single unit of Fresh frozen plasma and cryoprecipitate comprises $220 \mathrm{ml}$ and $15 \mathrm{ml}$ respectively.

Table-3: Indications of Packed Red blood cell transfusion observed during the study period.

\begin{tabular}{|l|l|l|}
\hline \multicolumn{1}{|c|}{ Indications } & Units & \multicolumn{1}{|c|}{$(\%)$} \\
\hline Traumatic bleeding & 1097 & 14 \\
\hline Surgical bleeding & 862 & 11 \\
\hline Hemolytic anemia & 1725 & 22 \\
\hline Obstetric indications during delivery & 1415 & 18 \\
\hline Aplastic anemia & 1254 & 16 \\
\hline $\begin{array}{l}\text { Severe anemia with } \mathrm{Hb}<3 \mathrm{~g} / \text { dl associated with failure } \\
\text { symptoms }\end{array}$ & 235 & 3 \\
\hline Acute blood loss $>40 \mathrm{ml}$ of blood volume & 940 & 12 \\
\hline Thalassemia & 313 & 4 \\
\hline Total & 7841 & 100 \\
\hline
\end{tabular}

Table-4: Indications observed for Fresh Frozen Plasma transfusion during the study period.

\begin{tabular}{|l|l|l|}
\hline \multicolumn{1}{|c|}{ Indications } & Units & Percentage \\
\hline Active bleeding & 1439 & 37 \\
\hline Liver diseases and coagulation factor deficiencies & 855 & 22 \\
\hline Disseminated intravascular coagulation & 233 & 6 \\
\hline Coagulopathy in massive transfusion & 117 & 3 \\
\hline Thrombotic thrombocytopenic purpura & 155 & 4 \\
\hline Hypovolemia and Poisoning & 700 & 18 \\
\hline $\begin{array}{l}\text { Associated Vitamin K and coagulation factor } \\
\text { deficiencies }\end{array}$ & 312 & 8 \\
\hline Congenital coagulation factor deficiencies & & \\
\hline Total & 78 & 2 \\
\hline
\end{tabular}

Table-5: Indications observed for Whole blood transfusion during the study period.

\begin{tabular}{|l|l|l|}
\hline \multicolumn{1}{|c|}{ Indications } & Units & \multicolumn{1}{|c|}{$(\%)$} \\
\hline $\begin{array}{l}\text { Anemia which includes all types of anemia except } \\
\text { Nutritional anemia }\end{array}$ & 897 & 46 \\
\hline Traumatic bleeding & 341 & 17 \\
\hline Surgical bleeding & 428 & 22 \\
\hline Exchange transfusion & 166 & 8.8 \\
\hline Liver diseases and coagulation factor deficiencies & 78 & 4 \\
\hline Hypovolemia and poisoning & 24 & 1.2 \\
\hline Obstetric causes during delivery & 21 & 1 \\
\hline Total & 1955 & 100 \\
\hline
\end{tabular}

Table-6: Indications of Platelet Concentrates transfusion observed during the study period.

\begin{tabular}{|l|l|l|}
\hline \multicolumn{1}{|c|}{ Indications } & Units & \multicolumn{1}{|c|}{$(\%)$} \\
\hline Platelet count $<5000 / \mu \mathrm{l}$ & 143 & 18 \\
\hline $\begin{array}{l}\text { Platelet count }-5000-10000 / \mu \mathrm{l} \text { with the risk of } \\
\text { infections like malaria and dengue and associated bone } \\
\text { marrow failure. }\end{array}$ & 223 & 28 \\
\hline $\begin{array}{l}\text { Platelet count }-10000-20000 / \mu \mathrm{l} \text { with bleeding } \\
\text { manifestations }\end{array}$ & 167 & 21 \\
\hline
\end{tabular}




\begin{tabular}{|l|l|l|}
\hline $\begin{array}{l}\text { Disseminated intravascular coagulation }- \text { with Platelet } \\
\text { count }<50,000 / \mu \mathrm{l}\end{array}$ & 111 & 14 \\
\hline Platelet count $-<70,000 / \mu l$ with Surgical indications & 105 & 13 \\
\hline Chemotherapy with Platelet count $<20000 / \mu l$ & 48 & 6 \\
\hline Total & 797 & 100 \\
\hline
\end{tabular}

Table-7: Gender distribution among the population who received a blood transfusion during the study period.

\begin{tabular}{|l|l|l|}
\hline \multicolumn{1}{|c|}{ Gender distribution } & \multicolumn{1}{c|}{ Transfusion received } & Percentage \\
\hline Male & 8647 & 66 \\
\hline Female & 4454 & 34 \\
\hline Total & 13,101 & 100 \\
\hline
\end{tabular}

Table-8: Age distribution among the population who received a blood transfusion during the study period.

\begin{tabular}{|l|l|l|}
\hline \multicolumn{1}{|c|}{ Age distribution } & \multicolumn{1}{c|}{ Transfusion received } & Percentage \\
\hline$<10$ years & 1048 & 8 \\
\hline $10-19$ years & 2096 & 16 \\
\hline $20-39$ years & 3669 & 28 \\
\hline $40-59$ years & 4323 & 33 \\
\hline$>60$ years & 1965 & 15 \\
\hline Total & 13,101 & 100 \\
\hline
\end{tabular}

Age and gender-wise distribution among the population who received blood transfusion irrespective of indications have also been noted in the study. Total patients who received blood transfusion noted during the study were 13,101 . Among that 8647 were male patients and 4454 female patients. Hence it is inferred that the male population is receiving blood transfusion more than females [Table-7]. Among the total population $(13,101)$ age-wise distribution, irrespective of indications. 1048 patients $(8 \%)$ been $<10$ years of age, 2096 patients were $(16 \%)$ between $10-19$ years of age, 3669 patients (28\%) were between 20 - 39 years of age. 4323 patients (33\%) were between 40- 59 years of age and 1965 patients were $>60$ years of age [Table-8].

\section{Discussion}

The pattern of usage among 14,511 units of blood components from June 2015 - June 2020 showed the frequency of usage of Packed Red Blood Cells more than Fresh Frozen Plasma and whole blood. The usage of whole blood found to be more than Platelet concentrates and Cryoprecipitate Fig. The most frequently used component was Packed Red blood cells - 7841 units (54\%) which is comparable with the previous studies by Rajesh Chandarya et. al (61.1.\%) [7]. The second most frequently used component was fresh frozen plasma - 3889 units
(26.8\%) followed by whole blood - 1955 units $(13.5 \%)$, platelet concentrates - 797 units (5.5\%), and cryoprecipitate - 29 units (0.2\%) [Table-2,3] which is comparable with previous studies by Richa Jain et. al [8], that is Fresh frozen plasma and platelets are frequently used component other than packed red blood cells. There has been an increase in demand and frequency of blood transfusion also noted and documented in the study as 1999 units (13.8\%) during 2015 to 2016, 2043 units (14\%) during 2016 to 2017,2935 units (20.2\%) during the period of 2017 to 2018,3532 units (24.2\%) during the period of 2018 to 2019 and 4011 units (27.8\%) during the period of 2019 to 2020 [Table-2].

The most frequently used component observed during the study was Packed red blood cells - 7841 units (54\%) and the yearly increase in demand for transfusion also noted as - 457 units (5.8\%) during 2015 to 2016,1067 units (13.6\%) during 2016 to 2017, 1903 units (24.2\%) during 2017 to 2018, 2172 units (27.7\%) during 2018 to 2019 and 2242 units (28.5\%) during 2019 to 2020 [Table-2,3]. Packed red blood cells have been indicated for transfusion most frequently for hemolytic anemias 1725 units (22\%) which is comparable with previous transfusion medicine studies by Luban NLC et. al, Galel S A et. al, that is the usage of packed red blood cells more in hemolytic anemias - 35\% $[13,14]$. For obstetric indications during delivery 1415 units (18\%) have been used. Other common indications observed for which packed red blood cells been utilized were aplastic anemia - 1254 units $(16 \%)$, traumatic bleeding - 1097 units ( $14 \%$ ), acute blood loss $>40 \mathrm{ml}$ of total blood volume - 940 units $(12 \%)$, surgical bleeding - 862 units $(11 \%)$, Thalassemia - 313 units (4\%) and severe anemia with $\mathrm{Hb}<3 \mathrm{~g} / \mathrm{dl}$ associated with failure symptoms - 235 units (3\%) [Table-4] which is found most indications similar to previous studies of other parts of south India by Dhaka et al [16].

The second most frequently used component was Fresh frozen plasma - 3889 units (26.8\%). There has been an increase in demand and transfusion of fresh frozen plasma been observed as - 194 units (5.0\%) during 2015 to 2016, 222 units (5.7\%) during 2016 to 2017, 867 units (22.3\%) during 2017 to 2018, 1112 units (28.6\%) during 2018 2019 and 1494 units (38.4\%) during 2019 to 2020 [Table-2,3]. Among the total units, the most commonly used indication was found to be active bleeding - 1439 units (37\%). The second frequent indication observed for which the Fresh frozen 
Plasma been used was liver diseases and coagulation factor deficiencies - 855 units (22\%). Other indications been observed for fresh frozen plasma transfusion were hypovolemia and poisoning - 700 units $(18 \%)$, associated vitamin $\mathrm{K}$ and coagulation factor deficiencies - 312 units (8\%), disseminated intravascular coagulation - 233 units (6\%), thrombotic thrombocytopenic purpura - 155 units (4\%), coagulopathy in massive transfusion 117 units (3\%) and congenital coagulation factor deficiencies - 78 units (2\%) [Table-5] which is comparable with previous transfusion studies by Roberts I, Murray et. al decompensated liver disease for which fresh frozen plasma indicated for transfusion mostly [11].

The third most frequently used blood product been used was found to be whole blood - 1955 units $(13.5 \%)$. It has been observed that reduction in the whole blood transfusion for therapy during the study period as 1278 units (65.5\%) during the period of 2015 - 2016, which has been gradually reduced yearly - 644 units (33.0\%) during 2016 to 2017,15 units $(0.7 \%)$ during 2017 to 2018,11 units (0.5\%) during 2018 to 2019 and 7 units (0.3\%) during the period of 2019 to 2020 [Table-2, 3]. Its evident that blood component therapy replaces the whole blood transfusion in preventing overload and complications to the patient. The most common indication for which whole blood transfused was anemia - 897 units (46\%) which is comparable with previous whole blood transfusion studied by Hass et.al, Jeanne A. et al, Petz, Lawrence, et al - severe anemia in various parts of world makes the need for emergency transfusion in life-threatening conditions $[20,23,27]$ Other common indications for whole blood transfusion been observed was surgical bleeding - 428 units (22\%), traumatic bleeding 341 units $(17 \%)$, exchange transfusion - 166 units $(8.8 \%)$, liver diseases and coagulation factor deficiencies - 78 units (4\%), hypovolemia and poisoning - 24 units $(1.2 \%)$ and obstetric indications during delivery - 21 (1\%) [Table-6] which is comparable with Dhaka et al, that is major indications of whole blood in anemia - 52\% (17).

Platelet concentrates were found to be the fourth frequently used blood component - 797 units (5.5\%) which are comparable with previous transfusion medicine studies by Opelz G - 10\% [28]. There has been an increase in demand and transfusion of platelet concentrates been observed as - 70 units (8.7\%) during 2015 to 2016, 108 units (13.5\%) during 2016 to 2017,345 units
(18.4\%) during 2017 to 2018, and 221 units (27.7\%) during $2018-2019$ and 253 units (31.7\%) during 2019 to 2020. [Table-2,3]. The most common indication for which platelet transfusion been done to patients was found to be platelet count $-5000-10,000 / \mu$ with the risk of infections and bone marrow failure - 223 units (28\%). Other common indications have been observed were patients having platelet count $10000-20000 /$ ul with bleeding manifestations - 167 units (21\%), platelet count < 5000/ ul - 143 units $(18 \%)$, disseminated intravascular coagulation - 111 units (14\%), platelet count $<70,000 /$ ul with surgical indications - 105 units (13\%) and chemotherapy patients < $20000 /$ ul - 48 units (6\%) [Table-7] which is found to have similar indications of platelet transfusion with platelet count range of $5000-70,000 / u l$ from the studies by Dhaka et al, Robinson $\mathrm{J}(17,30)$.

The less frequently used component was Cryoprecipitate - 29 units $(0.2 \%)$. No transfusion have been found during 2015 to 2016, 2 units (7.0\%) were used during 2016 to 2017,5 units (17.2\%) during 2017 to 2018 and 7 units (24.1\%) during 2018 - 2019 and 15 units (51.7\%) during 2019 to 2020 [Table-2,3]. The most common indications noted for cryoprecipitate transfusion were von Willebrand disease and hemophilia $A$ (factor VIII deficiency) - 21 units (72\%). For rapid surgical wound healing, fibrinogen rich concentrate has been used (38\%) which is comparable with the previous results by Dhaka et al, Rowley SD $(17,31)$ - most part of cryoprecipitate transfusion indicated in von Willebrand disease and hemophilia A (75\%). With awareness creation and frequent clinical collaborations, and increased demand has been observed. With age and gender-specific findings, it is been inferred that patients who received critical blood transfusion were between 20 - 39 years of age which is comparable with previous age-specific transfusion studies by Petz, Lawrence [27] where most transfusion been done in adult age groups been found.

\section{Limitations}

The study limits to analyze the pattern of usage of major four blood components which have been prepared in the blood bank. Further, the study to be extended to all other minor blood components of plasma protein derivatives and leukocytes to know the overall pattern of usage. And also through this study, analysis of the most common indications for each component irrespective of the age of the 
Recipients for transfusion was done. Hence further extension of this study can be made for age-specific indications for which the blood components are used to minimize immediate as well as long term sequelae of transfusions.

\section{Conclusion}

There has been an increase in the usage of blood products yearly to meet the clinical demand in treating patients with various morbidities. Instead of whole blood transfusion, specific blood component transfusion is encouraged for specific indications to reduce non-essential overload to the patients, which has been achieved in our department of transfusion medicine.

This is observed clearly in the present study. Preparation of blood component which has been frequently used (packed red cells) in our tertiary care hospital is encouraged which is also evident from the present study. Prevalence of anemia, thrombocytopenia with the risk of infections like malaria and dengue, von Willebrand disease, and trauma among the population nearby have been noted as other conditions worth in-depth study in relation to transfusion practice, in the patients from this area.

\section{What does the study add to the existing knowledge}

The highest achievement in this new modern era in the field of Transfusion medicine is the separation of one unit of blood into its various components for the transfusion so that more Blood component transfusions must be encouraged than the whole blood transfusion, to minimize avoidable transfusion reactions, allogeneic sensitization, volume overload and to use one unit of blood to save many lives. This simple study can be done in all the institutions to know the common indications and pattern of usage of blood components of blood transfusion in various geographical areas to promote the economy of voluntarily donated blood to save many lives with one unit of blood.

\section{Author's contribution}

Dr. Jeevaraj Giridharan; Concept, manuscript preparation

Dr. V. Sarada: Manuscript preparation, data analysis

\section{Acknowledgments}

The authors are thankful to the Chairman, the Dean, and the Medical superintendent, Institutional scientific and ethical committee for the approval to conduct the study.

\section{Reference}

01. Klein GH, David J. "The transfusion of blood, blood components and plasma derivatives" InMollison's Blood transfusion in Clinical Medicine. 12thed, Black well Pub, oxford. 2013.

Available at: [Article] [Crossref]

02. RK Saran. Transfusion Medicine Technical Manual, Ministry of Health and Family welfare. Government of India, New Delhi; 2nd ed. 2003. [Crossref]

03. Verma A. Blood component therapy. Indian J Pediatr. 2008;75(7)717.

doi: $\quad 10.1007 / \mathrm{s} 12098-008-0136-0 \quad$ [Crossref]

04. Bell EF, Strauss RG, Widness JA, Mahoney LT, Mock DM, Seward VJ, et al. Randomized Trial of Liberal Versus Restrictive Guidelines for Red Blood Cell Transfusion in Preterm Infants. Pediatr. 2005;115(6)1685-1691. doi: 10.1542/peds.2004-1884 [Crossref]

05. Jain R, Jose B, Coshic P, Agarwal R, Deorari AK. Blood and blood component therapy in neonates. The Indian J Pediatr. 2008;75(5)489495.

doi: $\quad 10.1007 / \mathrm{s} 12098-008-0076-8 \quad$ [Crossref]

06. Murray NA, Roberts IAG. Neonatal transfusion practice. Arch Dis Child Fet Neonate. 2004;89(2)101-107.

doi: 10.1136/adc.2002.019760 [Crossref]

07. Chandarya R, Wander GS, Gupta P. Blood component therapy- Which, When and how much. J Anaesthesiol Clin Pharmacol. $2011 ; 27(2) 278$.

doi: 10.4103/0970-9185.81849 [Crossref]

08. GR. Study of blood component therapy in neonates. Int J Sci Res. 2015;4(3)196-200.

[Crossref] 
09. Richa Jain, Bipin Jose, Poonam Coshic, Ramesh Agarwal, Ashok K Deorari. "AIIMS- NICU protocols" 2008. British Committee for Standards in Haematology. Accessed on April 20, 2008.

[Crossref]

10. Choudhury N, Phadke S. Transfusion transmitted diseases. Indian J Pediatr. 2001;68;951-958.

doi: $10.1007 /$ BF02722595 [Crossref]

11. Roberts I, Murray NA. Neonatal thrombocytopenia- causes and management. Arch Dis Child Fet Neonate. 2003;88(5)F359364.

doi: $10.1136 /$ fn.88.5.F359 [Crossref]

12. Tucci M. Goal-directed blood transfusion therapies Current Concepts in Pediatric Critical Care. Refresher Course. accessed on April 15, 2008.

available at http//sccmcms.scom.org [Crossref]

13. Luban NLC. Massive transfusion in Neonates. Transfus Med Rev. 1995;9(3)200-214.

doi: $10.1016 /$ S0887-7963(05)80110-5 [Crossref]

14. Galel SA, Fontaine MJ. Hazards of Neonatal Blood Transfusion. Neo Reviews. 2006;7(2)e 6975.

[Crossref]

15. Yang X, Ahmed S, Chandrasekaran V. Transfusion-related acute lung injury resulting from designated blood transfusion between mother and child- a report of two cases. Am J Clin Pathol. 2004;121(4)590-592.

doi: $\quad 10.1309 /$ kntu-ctna-gl5w-7r1r $\quad$ [Crossref]

16. Mamatha SV, Chaithra H, Susmitha NS, Anand R. A Retrospective study of analysis of reasons for discard of blood and blood components. Trop J Pathol Microbiol. 2018;4(3)276-280. doi: 10.17511/jopm.2018.i03.07 [Crossref]

17. Khodabux CM, Hach KEA, Von Lindern JS, Brouwers $\mathrm{H}$, Walther FJ, Brand A. A comparative study on transfusion practice and outcome in two Dutch tertiary neonatal centres. Transfus Med. 2009;19(4)195-201.

doi: 10.1186/1471-2431-11-48 [Crossref]
18. Galel SA. Therapeutic techniques- Selection of Blood Components for Neonatal Transfusion. Neo Rev. 2005;6;e351-e355.

[Crossref]

19. Giridharan J, Ramalingam Royal College of Physicians of Edinburgh. Consensus statement on red cell transfusion. Transfus Med. $1994 ; 4 ; 177-178$.

[Crossref]

20. Hass FJIM, van Rhenen DJ. Neonatology inBlood Transfusion Guidelines, Hass FJIM, van Rhenen DJ eds, National Users sanquin Blood Supply. Netherland. 2011;p146-164.

[Crossref]

21. Marwaka N, Chaudry RK. Blood Groups; Blood Transfusion- AIDS in; de Gruchy's Clinical Haematology in Medical Practice, Saxena R, Pati HP eds, Wiley India. New Delhi. 2013;p 432451.

[Crossref]

22. Jeanne AL, Ness PM. Current approaches to Red Cell Transfusion. Seminars in Hematology. Vol 33, no 4, 1996.

[Crossref]

23. Ala FA, Greaves M, Jones J, Levin M, Machin SJ, Morgan $C$, et al. Guidelines for the use of fresh frozen plasma. Tansfus Med. 1992;2(1)57-63. doi: 10.1111/j.1365-3148.1992.tb00135.x [Crossref]

24. Voak D, Cann R, Finney RD, Fraser ID, Mitchell R, Murphy MF. Guidelines for administration of blood products- transfusion of infants and neonates. Transfus Med. 1994;4(1)63-69. doi: 10.1111/j.1365-3148.1994.tb00245.x [Crossref]

25. Unit BS, World Health Organization. Developing a national policy and guidelines on the clinical use of blood- recommendations. World Health Organization. 1998.

[Crossref]

26. Petz, Lawrence, D. and Swisher, Scott, N. Clinical Practice of Transfusion Medicine, Sec Edn. Chuchill Livingstone. 1989 [Crossref]

27. Robinson J, Malik A, Partha P, Bodmer JG, Marsh SG. IMGT/HLA database-a sequence database for the human major histocompatibility complex. Tissue Antigens. 2000;55(3)280-287. doi: $10.1034 /$ j.1399-0039.2000.550314.x [Crossref] 
28. Opelz G. Analysis of the 'NIMA effect' in renal transplantation, Collaborative Transplant Study. Clin Transpl. 1990;63-67.

doi: 10.1038/s41409-018-0345-8 [Crossref]

29. Race RR, Sanger, Ruth. Blood Groups in Man, 6th Ed, Blankwell Scientific Publication. Oxford. 1975.

doi: 10.1002/ajpa.1330120223 [Crossref]

30. Rowley SD, Bensinger WI, Gooley TA, Buckner $C D$, et al. The effect of cell concentration of bone marrow and peripheral blood stem cell cryopreservation. Blood. 1994;83(9)2731-2736. doi: 10.1182/blood.V83.9.2731.2731 [Crossref] 